\title{
REVIEW
}

\section{Functional profiling of the gut microbiome in disease-associated inflammation}

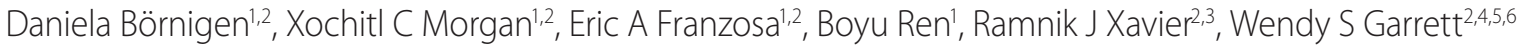 \\ and Curtis Huttenhower, ${ }^{1,2 *}$
}

\begin{abstract}
The microbial residents of the human gut are a major factor in the development and lifelong maintenance of health. The gut microbiota differs to a large degree from person to person and has an important influence on health and disease due to its interaction with the human immune system. Its overall composition and microbial ecology have been implicated in many autoimmune diseases, and it represents a particularly important area for translational research as a new target for diagnostics and therapeutics in complex inflammatory conditions. Determining the biomolecular mechanisms by which altered microbial communities contribute to human disease will be an important outcome of current functional studies of the human microbiome. In this review, we discuss functional profiling of the human microbiome using metagenomic and metatranscriptomic approaches, focusing on the implications for inflammatory conditions such as inflammatory bowel disease and rheumatoid arthritis. Common themes in gut microbial ecology have emerged among these diverse diseases, but they have not yet been linked to targetable mechanisms such as microbial gene and genome composition, pathway and transcript activity, and metabolism. Combining these microbial activities with host gene, transcript and metabolic information will be necessary to understand how and why these complex interacting systems are altered in disease-associated inflammation.
\end{abstract}

\section{Human microbiome structure and function}

The human gut is colonized by a large variety of microbial species that differ among healthy people $[1,2]$. Owing to the direct links between the human microbiome and the immune system, disruptions of the microbial ecology of the microbiome (dysbioses) have been implicated in many diseases, particularly those involving systemic or localized inflammation (Figure 1) [3-6]. This raises two exciting possibilities for the translation of basic research to clinical practice. The first is the use of the human microbiome as a diagnostic tool to predict disease risk, patient outcomes or response to treatment. The second is the eventual use of the microbiome as a therapeutic target, since microbial composition and metabolic activity are modifiable with relative ease by factors such as diet [7-9], the environment [10] and pharmaceuticals [11]. To realize this potential, however, a deeper understanding of biomolecular activity in these microbial communities will need to be developed by means of functional profiling of the human microbiome.

The gut microbiome has both the greatest microbial density in the human body and is the site at which microbes are most exposed to the immune system. This has led to its implication in a range of autoimmune diseases affecting the gastrointestinal tract [12], such as inflammatory bowel disease [13], colorectal cancer [4], type 1 diabetes [5] and metabolic syndromes [14]. Owing to its extensive interaction with the systemic immune system, however, the gut microbiome also contributes to the activity of the enteric nervous system (neurogastroenterological disorders [15]), extra-intestinal tissues (rheumatoid arthritis [16], allergy and atopy [17]), and the skin (atopic dermatitis [18]). In many of these diseases, genetic and environmental factors are known to play a role, but the biomolecular mechanisms linking microbial communities to disease are still unknown. Further functional profiling by metagenomics, meta\footnotetext{
transcriptomics and additional modalities will thus be required to understand how and why microbial genes and genome compositions, pathway and transcript activities, and metabolic processes are altered in inflammatory conditions, health and disease.

'Department of Biostatistics, Harvard School of Public Health, Boston, MA 02115, USA

Full list of author information is available at the end of the article 


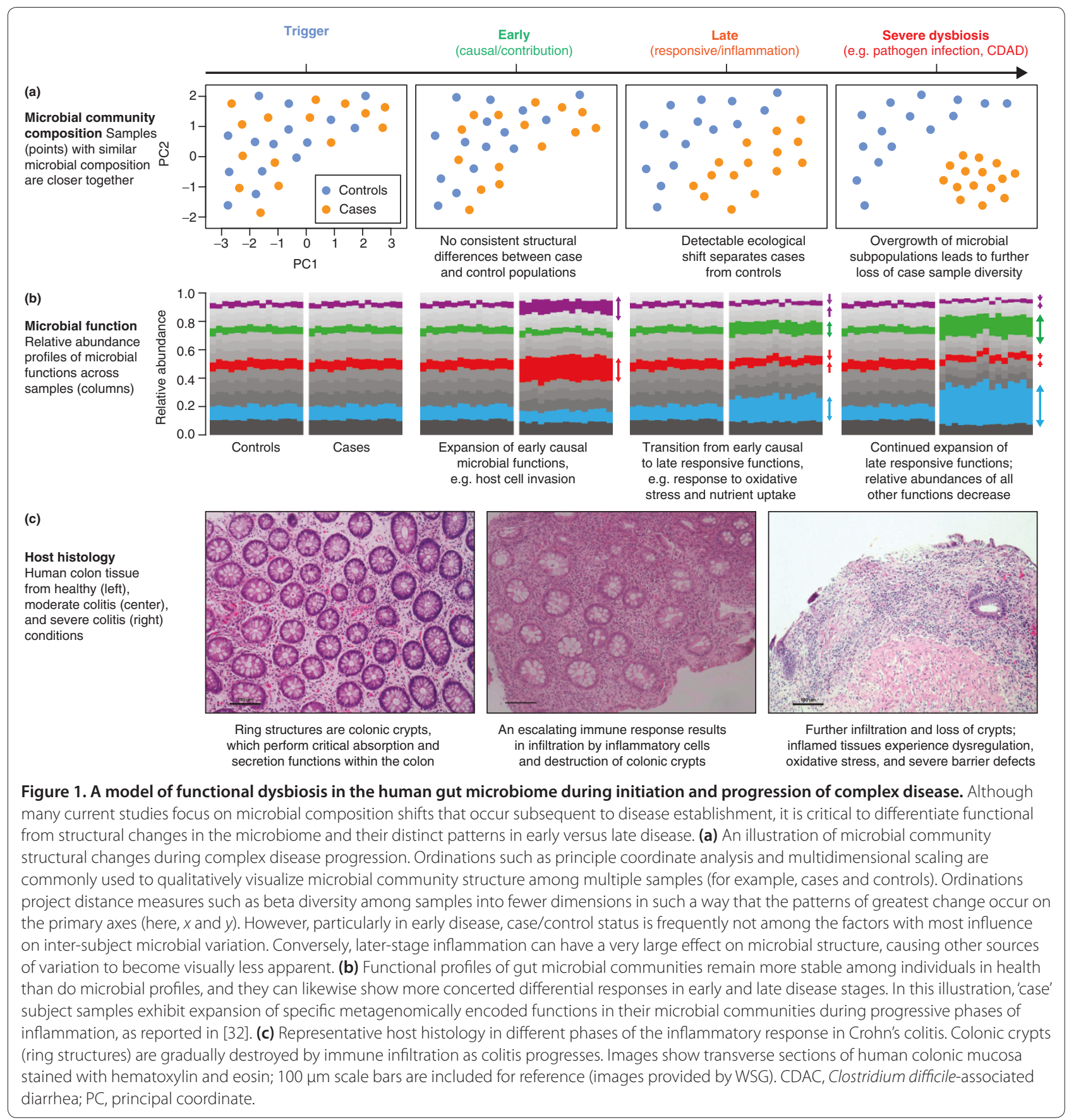

As in single-species systems biology, various meta'omic tools can provide insight into multiple levels of biological regulation in the microbiome, including the detection of microbial organisms, genes, variants, pathways or metabolic functions characterizing the microbial community in an uncultured sample, such as fecal samples or mouth rinses. Microbial ecology has most extensively been studied using targeted 16S rRNA gene sequencing, but this provides only indirect information on molecular activities and will not be the focus of this review. Instead, we will focus on approaches that provide more direct information on biomolecular function within a microbial community, such as metagenomic shotgun sequencing of whole-community DNA to provide a survey of the overall genetic potential of a microbiome. Transcriptional activity can likewise be assayed by metatranscriptomic cDNA sequencing to identify regulatory activity occurring rapidly in response to changes in environment. Whole-community metaproteomics and metabolomics are currently less common, but each again captures 
further downstream aspects of both microbial and host molecular activity [19]. In this review, we discuss functional profiling of the human gut microbiome using metagenomics and metatranscriptomics in inflammatory diseases to gain insight into the microbial species, pathways and metabolites, as well as host genes, transcripts and pathways that are altered during chronic inflammatory conditions.

\section{The gut microbiome}

Humans are born almost sterile, but during birth and early development they are rapidly and dynamically colonized by microbes throughout the body [20]. These reside primarily in the gut and include bacteria, viruses and, to a lesser degree, archaea and eukaryotic microbes $[1,21]$. The number of microbial genes involved in establishing and maintaining the community's ecology is immense, totaling $5,000,000$ or more $[1,21]$. This genetic repertoire interacts with that of the host and with environmental factors to create and maintain a cellular system with a metabolic and regulatory capacity comparable to that of complex human tissues [22]. Indeed, in the absence of microbes, neither host gut physiology nor the immune system develop normally [23]. The distribution of microbes throughout the gut is highly structured and dedicated to a variety of biological functions (Box 1).

Inflammation seems to exert effects to which the gut microbiota is particularly sensitive, and studies with the mucosal disruptant dextran sodium sulfate, which elicits colonic inflammation in wild-type mice, have demonstrated that inflammation affects the microbiota [24]. Inflammation results in a cascade of cellular and molecular effectors that can be directly bactericidal or generate substantial environmental stress for a microbial community. In retrospect, it is intuitive that inflammatory bowel disease, celiac disease, rheumatoid arthritis and other chronic inflammatory conditions represent one of the largest families of known microbiome-perturbing human diseases. The additional roles of symbiotic microbial stimulation of innate and adaptive immunity in the gut and training of systemic immunity are much less well understood, but they undoubtedly function in the triggering, maintenance and remission of inflammatory conditions.

\section{Gut microbes in chronic inflammatory and autoimmune disease Inflammatory bowel diseases}

It has long been accepted that the inflammatory bowel diseases - Crohn's disease and ulcerative colitis - occur in conjunction with a dysregulated host immune response to the normal gut microbiome, and include strong genetic components [25]. Recent genome-wide association studies (GWAS) have been very successful in revealing the responsible human genes [3]. However, diseasecausing functional defects have only been explained for a few genes (for example, NOD2, IL23R), which are also intimately tied to the microbiome by crucial roles in controlling microbial infiltration in the gut [26].

Assessing microbial functional responses in tandem with additional human genetic risk variants may help to better identify their functional consequences in vivo. For example, low plasma levels of vitamin D (which inhibit pro-inflammatory p38 kinase signaling [27], affect innate immune function [28] and may promote development of T regulatory cells [29]) are associated with an increased risk of Crohn's disease [25]. The gut microbiome can alter both the distribution and expression of vitamin D receptors in the gut [30], suggesting that natural microbial variation is a contributing influence on vitamin $D$ metabolism. Dietary fiber, which is metabolized by the gut microbiota to anti-inflammatory short-chain fatty acids (SCFAs), has been found to be protective against inflammatory bowel disease in some studies [25]. Both low vitamin $\mathrm{D}$ levels and dietary fiber intake represent a host-microbe metabolic interaction that potentially affects inflammatory bowel disease onset or activity.

The widely observed reduction in diversity of gut microbial ecology in inflammatory bowel disease $[31,32]$ may be a consequence of more specific functional changes. For example, increased levels of Enterobacteriaceae may be the result of differences in this taxon's ability to tolerate inflammation-associated redox stress [33], and SCFA-producing Clostridia may be outcompeted by more generalist or opportunistic Enterobacteriaceae, resulting in decreased microbial SCFA production and contributing to a self-reinforcing proinflammatory state incorporating both host immune and microbial metabolic components [32]. Such hostmicrobe and microbe-microbe regulatory feedback loops provide novel potential targets for pharmaceutical and probiotic development, since both the introduction of specific microbes [34] and the disruption of individual microbial processes such as redox metabolism [35] have the potential to mitigate inflammatory processes in the gut.

\section{Rheumatoid arthritis}

Rheumatoid arthritis is a systemic inflammatory disorder that manifests as an inflammatory response to synovial tissues. Recent studies have associated the oral microbial community with the disease, with rheumatoid arthritis patients having a higher prevalence of periodontitis and tooth loss [36]. In the gut, several studies have shown that diet can have a therapeutic effect on rheumatoid arthritis in conjunction with decreased inflammation [37]. Some initial studies have been performed to gain 


\section{Box 1. Influences on gut microbiota structure and function}

Overall, the gut microbiota comprises residents of the stomach, small intestine and large intestine [98]. However, owing to pH stress and bile salt toxicity, microbial biomass is very low before the ileum. The vast majority (more than 99\%) of the gut microbiome is found in the colon, where (among other activities) it breaks down indigestible fibers and ferments them into SCFAs. These are an essential fuel for colonocytes, maintain colon health, and provide approximately $10 \%$ of dietary energy from a Western diet. The colon contains by far the most microbial cells in a typical human body, dominated by the Bacteroidetes and Firmicutes phyla, with lesser but still important consortia of Proteobacteria, Actinobacteria, other bacterial clades, and Archaea. Both stool samples and biopsies have been extensively investigated as representatives of the colonic mucosal and luminal communities; comparable taxa are detected regardless of sample origin but in different relative abundances [32], reflecting microbial dispersion and niche specialization.

The composition of the gut microbiome is influenced by both genetics and environmental factors such as diet [6] and age [32]. For example, monozygotic twins were found to be concordant for carriage of Methanobrevibacter smithii at a much higher rate than dizygotic twins (74\% versus 14\%) [99], although it is difficult to distinguish this effect from that of co-habitation [100]. The dynamics of microbial responses to perturbations are particularly critical to consider during early life and beyond [101-103], and longitudinal sampling of complex communities is an active area of research [104].

The gut microbiota seems to be resilient to short-term dietary change, as even profound shifts in diet (such as from a high-fat/high-protein to a low-fat/low-protein diet) tend to quickly change the relative abundance of microbial taxa but not their presence or absence [105,106]. However, humans from different environments (with correspondingly different long-term diets) do maintain distinct microbiomes. For instance, a recent study compared healthy children from Italy and Burkina Faso - the latter of whom consumed a much higher-fiber diet and very little meat. The microbiota of the children from Burkina Faso was much more phylogenetically diverse and had approximately fourfold higher fecal butyrate concentrations, indicating microbial communities more efficient at extracting nutrients from fiber than those of the Italian children [9]. Interestingly, abundant Enterobacteriaceae, decreased intestinal biodiversity and decreased intestinal levels of butyrate are all associated with inflammatory bowel disease, which is much less common in non-Western countries [32,107].

Non-dietary perturbations, such as antibiotics and other pharmaceuticals, also profoundly affect both host and microbiome. A study of mice given long-term, sub-therapeutic doses of antibiotics found large shifts in the microbial community that led to an increase in SCFAs. These in turn contributed to a corresponding increase in host adiposity, although the mice did not eat more [11]. Higher doses of antibiotics disrupt even more of a host's endogenous microbial community, potentially leaving human patients susceptible to opportunistic infections such as Clostridium difficile, which can precipitate a vicious cycle of microbial community disruption [108].

more insight into the functional consequences of changes in the intestinal microbiome and their impact on inflammation and immune responses [38]. For example, Lactobacillus bifidus was shown to trigger arthritis in a mouse model (IL-1-receptor-antagonist-deficient mice), which was specifically driven by an imbalance in T-cell homeostasis and mediated through Toll-like receptor (TLR2 and TLR4) signaling [39]. In this mouse model, which is known to spontaneously develop an autoimmune T-cell-mediated arthritis due to excessive interleukin (IL)-1 signaling [40], TLR2 and TLR4 were involved in the expression of autoimmune arthritis. Specifically, TLR2 slowed the progression of arthritis by controlling the function of $\mathrm{T}$ regulatory cells and regulating interferon (IFN)- $\gamma$-producing $\mathrm{T}$ helper 1 (Th1) cells, and TLR4 increased the severity of the disease by modulating the T helper 17 (Th17)-cell population and IL-17 production. Another study found that autoimmune arthritis was strongly attenuated in a $\mathrm{K} / \mathrm{BxN}$ mouse model under germ-free conditions, accompanied by reductions in serum autoantibody titers, splenic autoantibody-secreting cells, germinal centers, and the splenic Th17 cell population [16]. The authors observed that their mouse model had a dearth of IL-17-producing $\mathrm{T}$ cells, which could be reversed by introducing segmented filamentous bacteria into the gut of germ-free-housed mice, provoking rapid onset of the disease. Taken together, these studies suggest that both the oral and gut microbiome may trigger rheumatoid arthritis by inciting local inflammatory responses in the host, but do not elucidate what mechanism might be at play in systematizing this response or targeting it to the synovium.

\section{Allergy and atopy}

The role of the microbiome in allergy and asthma is the foundation of the widely recognized 'hygiene hypothesis', which states that a combination of improved hygiene, frequent use of antibiotics, or vaccinations may lead to reduced bacterial and viral infections, and to an altered immune system that responds inappropriately to innocuous substances [41]. Recent functional studies of symbiotic microbes in these conditions have been primarily epidemiological, and have targeted environmental risk and preventive factors such as lifestyle, infections and diet [42]. Perhaps the strongest results have arisen from investigations of early life exposures to environmental microbes, establishing a link between home allergen levels, lymphocyte proliferation and wheeze in children at high risk for asthma [43]. In several such studies, early life 'urban' allergen exposures have been associated with later asthma and allergy risk, whereas environmental microbial exposures have generally been protective. 
Although the skin microbiome has been the main habitat investigated for atopic skin diseases [44], the gut microbiome's extensive interaction with the immune system has also led to it being indirectly linked with atopic manifestations and sensitization [17], and directly with atopic dermatitis in infants [18]. These studies revealed several microbes, such as Bifidobacterium, Staphylococcus, Escherichia coli and Clostridium difficile, that were associated with a higher risk of atopic dermatitis in children, albeit not yet with a functional explanation. Interestingly, maternal intestinal and vaginal Bifidobacteria, one of the most important groups of early life microbes, have an incompletely characterized influence on the establishment of Bifidobacteria during infant gut colonization $[45,46]$. A recent cohort study investigating the influence of maternal gut microbiota on wheezing in early childhood found an association between higher total maternal aerobes and Enterococci with increased risk of infant wheeze. A core concept in the hygiene hypothesis is that microbial exposures in early life may 'tune' immune responses and ensure hostimmune homeostasis over the human lifetime. CD4 $4^{+} \mathrm{T}$ helper cell and innate lymphoid cell populations and their effectors may be one component of this [41], and early life responses to specific microbial clades may participate in or trigger activation of these immune responses.

\section{Disorders of the brain-gut axis}

Bidirectional communication between the brain and the gut has long been recognized [47], and has become the focus of increasing research on the 'microbiome-gutbrain axis' [15]. Just as the microbiome affects the physical development of the gut, it can also influence mammalian brain development [48]. During adult life in rodents and insects, the composition of the gut microbiome has been found to influence a variety of complex behavioral traits, including anxiety [49] and mating preferences [50]. Potential mechanisms have been identified for associations between stress-related disorders (such as anxiety and depression) and the gut microbiome in laboratory mice [51]. In this study, for example, GABA transcriptional activity was found to be stimulated via the vagus nerve by Lactobacillus rhamnosus. Preliminary results in other systems suggest that early life stress may result in persistent changes to the gut microbiome, which in turn can contribute to symptoms resembling those seen in human psychiatric disorders [52]. Combining this with microbial metabolic responses to host hormones, as discussed earlier, and ongoing studies of the microbiome in weight loss [53], it seems likely that microbial products will be found to have a role in hunger signaling and host metabolic regulation as well.

One of the clearest links between the gut microbiota and neural disorders is in multiple sclerosis, by way of an autoimmune reaction. Multiple sclerosis is a chronic inflammatory disease of the nervous system notable for its T-cell responses to components of nerve fiber myelin sheaths [54]. Several loci associated with multiple sclerosis by GWAS are at or near genes with roles in Tcell-mediated immunity, and gut-resident viruses have been suggested as initial triggers of this autoimmune response [55]. Mycobacteria and their cell extracts have been implicated in a surprisingly wide range of immunoregulatory processes, and in particular are capable of suppressing central nervous system autoimmunity in the encephalomyelitis mouse model by altering T-cell migration, suppressing the IL-17 response, and inducing apoptosis of activated T cells [56]. The Bacillus CalmetteGuérin vaccination, which is prepared from an attenuated Mycobacterium bovis strain, was associated with decreased multiple sclerosis flare severity [57], and bacterial lipopolysaccharide was also shown to protect mice from central nervous system inflammation, by promoting the growth of neuroprotective $\mathrm{T}$ regulatory cells [58]. These findings are suggestive of host responses that may be triggered by metabolic or cellular components of the endogenous microbiota, but to date no specific microbial molecules have been identified as causative.

\section{Functional profiling of the microbiome}

The roles of the gut microbiota in inflammatory conditions have begun to be unraveled by functional profiling, or the assessment of host and microbial biomolecular activity in tandem with microbial community structure. Assessment using nucleotide sequencing is typically a two-step process. First, genes, proteins, or protein families in the community (and sometimes in the host) are quantified; second, individual gene families are merged into higher-level pathways, such as metabolic pathways and functional modules. There are several experimental assays and computational methods designed to accomplish these steps, and the choice of method depends on the nature of the microbial community under investigation, as well as the sequencing data available to describe it. Considerations in the choice and application of analysis methods are briefly summarized here and reviewed in depth elsewhere [59].

Functional information can be gleaned from almost any whole-community experimental data type; broadly, $16 \mathrm{~S}$ rRNA gene sequencing [60], metagenomic or metatranscriptomic shotgun sequencing [61], metaproteomics [62] and/or metabolomics [63]. Host genetics and/or gene expression can also be considered, and host products are typically included in metabolite, protein, and sometimes RNA datasets. Most initial data acquisition and informatics are the same for whole-community studies as for single-organism studies, except that first, samples must be handled with care in order to preserve, lyse and 
extract a wide range of microbial organisms without bias $[64,65]$, and second, computational interpretation in the presence of multiple underlying genomes can be challenging. Metagenomics and metatranscriptomics (together meta'omics) currently represent the most costeffective balance between functional and structural data.

Meta'omic data are typically interpreted by first assigning sequences to gene families [59]. This can be done by assembling short reads into contigs and identifying protein-coding sequences (CDSs, using approaches comparable to annotating single genomes), or reads can be assigned directly to gene or protein families. The latter approach may either map reads to annotated CDSs in microbial reference genomes, or they may be searched against databases of characterized protein families. In either case, the result is a profile of microbial gene families present in a community and their relative metagenomic or metatranscriptomic abundances. Gene family identification systems amenable to this process include the KEGG Orthology, COG [66], NOG [67], Pfam [68] and UniRef [69]. Each of these satisfy the necessary criterion of a database of systematically identified protein sequence groups, with each individual sequence representing a family member within an individual organism. For communities described by $16 \mathrm{~S}$ sequencing data rather than shotgun data, direct inferences cannot be made about the CDSs present in the community, and instead one must rely on inferring the presence of particular functions by associating $16 \mathrm{~S}$ sequences with gene content from annotated reference genomes [70].

Individual gene families profiled in any of these ways can then be hierarchically organized for ease of interpretation, just as individual microbes are organized taxonomically or phylogenetically. This is a critical step, as catalogs typically describe anywhere from tens of thousands to millions of gene families in the gut microbiome, but no pathway catalogs exist so far that are specifically appropriate to microbial communities. Databases developed for single organisms do help this effort, such as KEGG [71], MetaCyc [72] and SEED [73]. Integrated bioinformatics pipelines have been developed to streamline the multi-step processes described above, including IMG/M [74], MG-RAST [75], MEGAN [76] and HUMAnN [77]. Each of these procedures for functional sequence analysis provides researchers with an option for translating raw meta'omic sequence data into a more easily interpreted profile of the functional potential of a microbial community.

Functional profiling of the microbiome can be a timeconsuming process for samples characterized by a large amount of sequence data, as mapping these sequences to a gene family or reference genome databases is computationally intensive. However, once this mapping step is completed, subsequent analyses (such as merging gene families into pathways) proceed quickly, and can rapidly produce clinically relevant results. For example, screening an individual's gut microbiome profile or the microbiome of an infection for known antibiotic-resistance genes [78] can illuminate the resistance potential of a microbial community, informing treatment options. In addition, profiling the enzymatic composition of a patient's gut microbiome may indicate how the cells in that community will interact with pharmaceutical interventions; for example, whether they will metabolize them to inactive or potentially hazardous forms $[79,80]$. Last but not least, the early stages of diseases with microbial involvement are often not associated with dramatic changes in microbial community composition. However, the community's functional profile may reveal disease-linked perturbations at a much earlier stage of disease progression, leading to the possibility of using functional profiling to generate biomarkers for disease diagnosis (Figure 1).

\section{Functional profiling case studies in health and disease}

A comprehensive example of functional interpretation of the human microbiome can be found in the Human Microbiome Project (HMP), which provides both experimental protocols [81] and computational pipelines [1] for assessing the gut and other body sites. The results of the HMP provide a useful reference for gut microbiome function in health, providing a variety of public data from a cohort of 242 individuals, including both 16S rRNA gene and metagenomic shotgun sequencing [82] for the analysis of microbial communities and functional profiles. All subjects were clinically screened to ensure a high level of health [83], and these data represent a powerful set of tools for meta-analysis alongside new diseasefocused studies [8]. Within the study itself, it was shown that metagenomic carriage of metabolic pathways was stable among individuals even when microbial composition was not, and, of the recorded metadata, racial/ ethnic background showed one of the strongest associations between clinical metadata and either pathways or microbes. The magnitude of this effect was larger than that of age in this cohort, in which diet was not deeply characterized; these two factors have been associated independently with microbiome composition in other studies [6,32]. On the basis of these data [1], 118 stool samples from healthy individuals were profiled, highlighting a core gut microbiome that consists of stable pathways that are present despite variation in microbial abundances (Figure 2). These findings thus specify the range of normal structural and functional configurations in the microbial communities of a healthy Western population, and they provide a framework for future studies of human microbiome function. 


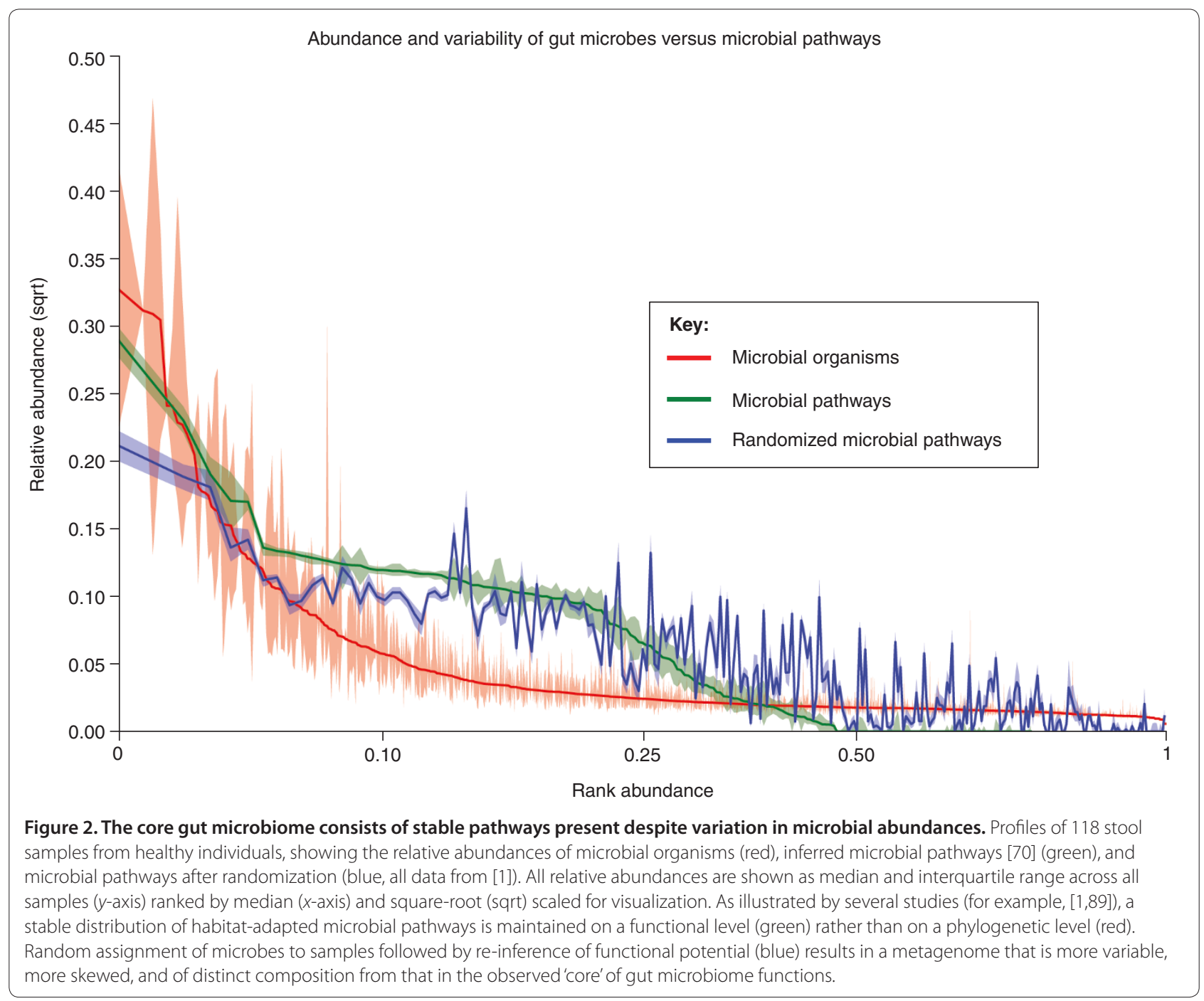

\section{Maintaining community function in health}

A companion project within the HMP characterized the function and composition of the digestive tract sites assayed by the project, comprising ten distinct body habitats (in the mouth, oropharynx and colon [84]). These microbial habitats formed four related areas of microbial community configurations: tooth hard surfaces; two distinct types of oral soft tissues and environments (cheek/gingiva/palate versus throat/tonsils/tongue/saliva); and the gut, as represented by stool samples. Metabolic profiling revealed a set of 'core' digestive tract pathways enriched in abundance throughout these communities, including pathways involved in the acquisition and export of metals, and cytochrome c heme lyase, an enzyme involved in porphyrin and chlorophyll metabolism. These pathways were unique in that most genes encoding exporters needed for heme tolerance (such as MtrCDE and $\mathrm{HrtAB}$ ) were not significantly associated with specific organisms in the study, and the gene encoding hemerythrin (responsible for oxygen transport in specific organisms) was detected at multiple body sites but was highly enriched in stool. Conversely, each of the four habitats was also enriched in more niche-specific metabolism, such as the $\beta$-glucosidase pathway in stool (involved in cellulose breakdown to $\beta$-D-glucose), glycolysis and pyruvate generation by glucose metabolism, and several pathways for ammonia utilization (such as the urea cycle and ornithine biosynthesis), as well as methane production. The oral cavity, conversely, showed enrichment for energy harvest pathways reliant on simple sugars (mannose, fructose, trehalose, and so on) and in many cases oxidative metabolism (especially when contrasting, for instance, supra- versus sub-gingival plaques). While in many cases these pathways were broadly phylogenetically distributed among diverse clades, others were tightly tied to just a few microbes (for example, hydrogen sulfide production by the Veillonella, Selenomonas and Prevotella genera). 
Perturbations of gut microbiome function in disease Both protective immune responses and dysregulation during autoimmunity are activated by signals initiated by innate immunity and driven by microbial stimuli [85]. Many studies have thus investigated microbial function in the gut microbiome in these diverse autoimmune diseases, with several recent examples including inflammatory bowel disease [31,32,86,87], rheumatoid arthritis [36], and allergy and atopy $[18,42,88]$ (as described earlier), as well as metabolic syndrome $[89,90]$ and neurological disorders [15,47-49]. As a T-cell-mediated metabolic disease, type 1 diabetes is another prime candidate for involvement of the gut microbiota $[5,10,91]$. Much current work on the function of the gut microbiome in type 1 diabetes relies on the non-obese diabetic (NOD) mouse model [92,93], a well-known system in which immune-mediated pancreatic $\beta$-cell destruction is triggered by gut microbial colonization [93]. Table 1 summarizes these and additional relationships among microbial organisms and pathways, as well as human genes and pathways, that are known to be involved in these inflammatory conditions.

A recent study investigated the human gut microbiome in malnourished children, specifically in kwashiorkor, a childhood protein-deficiency disease [6]. The authors first identified nine well-nourished twin pairs and 13 twin pairs who became discordant for kwashiorkor over the study period of 18 months. Fecal metagenomics showed age to be the greatest determining factor in gut microbial variation in healthy children, along with family membership and diet. Healthy children showed a steady progression toward a consistent microbiome common to older children, which did not take place in subjects suffering from kwashiorkor. Surprisingly, though, no significant changes in the functional composition of the gut microbiome occurred after treatment. Instead, several metabolic pathways were already significantly different in discordant twin pairs at the time of diagnosis, such as $\alpha$ mannosidase, an enzyme involved in glycan biosynthetic reactions and catabolism, and protein-N(PI)-phosphohistidine-sugar phosphotransferase, an enzyme involved in sugar catalysis. Microbial pathways including $\beta$ glucosidase and $\beta$-galactosidase activity remained significantly different in discordant twin pairs a month after cessation of treatment, suggesting substantial stability of changes induced in the microbiome by extreme environmental effects.

The authors subsequently transplanted fecal microbial communities from discordant twin pairs into gnotobiotic mice to identify features of the microbial community structure, metabolism, and host-microbial co-metabolism associated with donor health status and diet. In this mouse model, they found increased levels of the majority of SCFAs, carbohydrates, amino acids, nucleotides and lipid metabolism in cecal and fecal samples in mice receiving dietary treatment, whereas levels of several diand monosaccharides (maltose, gentibiose and tagatose) were decreased. When the mice (both healthy and with kwashiorkor) started treatment, the levels of nine amino acids (valine, leucine, isoleucine, methionine, phenylalanine, threonine, alanine, tyrosine and serine) rapidly increased. After returning to a normal diet, most of these amino acids remained higher in healthy mice than before therapy, but in the kwashiorkor group, these values fell to pre-treatment levels. This suggests that the stable alteration of the microbiome specifically influences its future ability to maintain healthy host-microbe metabolic interactions. Additionally, the authors found that the urinary excretion of the tricarboxylic acid (TCA) cycle intermediates 2-oxoglutarate, citrate, succinate and fumarate were closely coupled in healthy mice but decoupled in kwashiorkor. This disruption of the TCA cycle resulted in an increased succinate-to-fumarate ratio, possibly from inhibition or depletion of succinate. The authors suggested that this might be the result of kwashiorkor-specific generation of chemical products selectively inhibiting TCA cycle enzymes, making energy metabolism an even more extreme challenge for children with kwashiorkor exposed to a micro- and macronutrient-deficient, low-calorie diet.

This result provides an informative case study in that it traces a microbiome-linked human disease from population-level epidemiology through a validated molecular mechanism to potential diet-driven treatment. Although the resulting human health recommendations remain to be validated, it provides an example of a case in which the three major elements of functional gut microbiome profiling were used to derive an actionable result: broad sequencing-based surveys of the gut microbiome in a human population, deep sequencing and functional assays in a gnotobiotic mouse model to detail metabolic mechanisms, and subsequent follow-up profiling of a potential treatment in humans. Even in this relatively straightforward example, interplay between environmental factors, diet, variable microbial composition and age must all be taken into account to understand host-microbiome interactions in human disease.

\section{Functional profiling in the future: a perspective}

The past five years have seen an explosion of human microbiome studies, most of which have associated changes in microbial ecology with human health or the environment $[1,7,8,81,89,94]$. In almost no cases, though, do we yet know the causality, mechanism or relevance of these microbial shifts. In the few instances where specific biomolecular interactions have been addressed [95,96], they have begun to effectively indicate routes by which 
Table 1. Published relationships among microbial clades, pathways, and human genes and pathways involved in autoimmune diseases

\begin{tabular}{|c|c|c|c|c|c|}
\hline Disease & Microbes & Microbial pathways & Host pathways & Representative host genes & References \\
\hline $\begin{array}{l}\text { Inflammatory } \\
\text { bowel disease }\end{array}$ & $\begin{array}{l}\text { Enterobacteriaceae, } \\
\text { Roseburia, } \\
\text { Ruminococcaceae }\end{array}$ & $\begin{array}{l}\text { Glutathione metabolism and } \\
\text { transport, riboflavin metabolism, } \\
\text { short-chain fatty acid metabolism }\end{array}$ & $\begin{array}{l}\text { Autophagy, Th17, } \\
\text { T-cell responses and } \\
\text { cytokines, JAK-STAT, } \\
\text { NF-kB, microbial } \\
\text { sensing }\end{array}$ & $\begin{array}{l}\text { ATG16L1, CARD9, DUOX2, } \\
\text { IL 10, IL23R, IRGM, FUT2, } \\
\text { MHC, NCF4, NOD2 }\end{array}$ & $\begin{array}{c}{[3,25,31,32} \\
86,87 \\
107,109]\end{array}$ \\
\hline Type 1 diabetes & $\begin{array}{l}\text { Akkermansia, } \\
\text { Bacteroidales, } \\
\text { Lactobacillaceae }\end{array}$ & $\begin{array}{l}\text { Amino acid metabolism, } \\
\text { secondary metabolite } \\
\text { biosynthesis, butyrate production, } \\
\text { carbohydrate metabolism, } \\
\text { glycan biosynthesis and } \\
\text { metabolism, lactate production, } \\
\text { lipid metabolism, nucleotide } \\
\text { metabolism }\end{array}$ & $\begin{array}{l}\text { Innate immune } \\
\text { signaling, mucin, } \\
\text { MyD88, Toll-like } \\
\text { receptors }\end{array}$ & $\begin{array}{l}\text { CTLA4, IL2RA, IFIH1, INS, } \\
\text { MYD88, MHC, PTPN22, TLR }\end{array}$ & $\begin{array}{c}{[5,91} \\
110-116]\end{array}$ \\
\hline $\begin{array}{l}\text { Rheumatoid } \\
\text { arthritis }\end{array}$ & $\begin{array}{l}\text { Bacteroides fragilis, } \\
\text { Bacteroides vulgatus, } \\
\text { Clostridium coccoides, } \\
\text { Eubacterium rectale, } \\
\text { Klebsiella, Lactobacillus, } \\
\text { Porphyromonas, } \\
\text { Prevotella, SFB }\end{array}$ & - & $\begin{array}{l}\text { CD40, IL-2, NF-kB } \\
\text { activation, SAA or } \\
\text { CCL5 signaling, } \\
\text { T-cell activation and } \\
\text { response }\end{array}$ & $\begin{array}{l}\text { CD40, CCL21, HLA-DRB1, } \\
\text { IL2, IL17, IFNG, KIF5A, MHC, } \\
\text { TLR2, TLR4, TNF, TNFAIP3, } \\
\text { PRKCQ }\end{array}$ & $\begin{array}{c}{[38,117,} \\
118]\end{array}$ \\
\hline $\begin{array}{l}\text { Multiple } \\
\text { sclerosis }\end{array}$ & $\begin{array}{l}\text { Epstein-Barr virus, } \\
\text { Mycobacteria }\end{array}$ & Vitamin D metabolism & $\begin{array}{l}\text { Vitamin D, CD4 } \\
\text { T cells }\end{array}$ & $D R B 1, I L 2, I L 7, H L A, M H C$ & $\begin{array}{c}{[56,57} \\
119-121]\end{array}$ \\
\hline Allergy, atopy & $\begin{array}{l}\text { Aerobes, Bifidobacteria, } \\
\text { Enterococci, } \\
\text { Staphylococcus aureus, } \\
\text { Escherichia coli, } \\
\text { Clostridium difficile }\end{array}$ & - & $\begin{array}{l}\text { IgE antibody } \\
\text { regulation, vitamin D }\end{array}$ & $\begin{array}{l}\text { ADAM33, ADRB2, CD14TNF, } \\
\text { IL10, IL4, IL13, IL4RA, IFNG, } \\
\text { FLG, FCER1B, HLA-DRB1, } \\
\text { HLA-DQB1, MHC }\end{array}$ & $\begin{array}{r}{[17,18,45} \\
46,122-128]\end{array}$ \\
\hline
\end{tabular}

SFV, segmented filamentous bacteria.

microbiome shifts can be diagnostically interpreted or therapeutically targeted.

The recent history of cancer genomics suggests an important parallel for the next steps in translating human microbiome studies to the clinic. Early descriptive work in cancer functional profiling proved difficult to interpret or act on, and only a detailed understanding of molecular activities within the complex, mixed cellular population of a tumor allowed the creation of effective targeted therapies. The same necessity for deep biomolecular characterization is likely to hold true in the complex, mixed cellular population of a microbial community.

To this end, microbiome studies now have experimental design options that allow the integration of both descriptive and functional assays, as well as more convenient and holistic computational interpretation. Researchers must take advantage of these to test specific, wellcontrolled hypotheses in human subjects, model systems (mouse, zebrafish and others [97]), and in vitro (for example, cell culture and functional screens). Epithelial cell lines and synthetic systems (such as co-culture, microfluidics and organoids) represent an intriguing untapped resource. Conversely, large population surveys relating microbial structure to function (transcripts and proteins) have also not yet been performed and will establish an important baseline, building on references such as the HMP and MetaHIT.

Analytical limitations remain to be overcome in the translation of functional microbiome surveys to human health, both in our understanding of basic biological mechanisms and in our ability to leverage these data for clinical use. The former will require substantially more comprehensive integrative models of multi-microbe and host-microbe signaling, metabolic interaction, immunology and ecology than are available today. The latter, again not unlike personalized cancer therapies, in many cases still needs high-reliability, large-effect-size predictors of disease risk and outcome in humans to be clinically actionable. To address these challenges, carefully designed pre-clinical experimental systems are needed, particularly longitudinal prospective and outcome-based studies in human populations to detail the dynamics of microbial function during disease onset, treatment and resolution. In the future, in combination with novel computational models and the continued incorporation of sequencing technologies into the clinic, such investigations will lead us towards a deeper understanding of microbial communities and their functional roles in health, inflammation and disease. 


\section{Abbreviations}

CDS, coding sequence; GWAS, genome-wide association studies; HMP, Human Microbiome Project; IFN, interferon; IL, interleukin; NOD, non-obese diabetic; SCFAs, short-chain fatty acids; TCA, tricarboxylic acid.

\section{Competing interests}

The authors declare that they have no competing interests.

\section{Acknowledgements}

The authors would like to thank Timothy Tickle and Levi Waldron for assistance with figures, Carolyn Ingalls and Nicole Levesque for their editorial assistance, and the members of the Huttenhower laboratory for their input and thoughtful discussions. This work was supported by National Science Foundation grant DBI-1053486 (CH), Danone research grant PLF-5972-GD (WSG), National Institutes of Health (NIH) grant 1R01HG005969 (CH), NIH R01CA154426 (WSG), K08AI078942 (WSG), R01GM099531 (WSG), a Burrough Wellcome Career in Medical Sciences Award (WSG), a Searle Scholars Award (WSG), Cancer Research Institute Investigator, NIH/NIDDK R01DK092405 (RJX), the Crohn's and Colitis Foundation of America ( $\mathrm{CH}$ and RJX), and the Juvenile Diabetes Research Foundation (RJX).

\section{Author details}

'Department of Biostatistics, Harvard School of Public Health, Boston, MA 02115, USA. ${ }^{2}$ The Broad Institute of MIT and Harvard, Cambridge, MA 02142, USA. ${ }^{3}$ Gastrointestinal Unit, Massachusetts General Hospital, Boston, MA 02115, USA. ${ }^{4}$ Department of Immunology and Infectious Diseases, Harvard School of Public Health, Boston, MA 02115, USA. ${ }^{5}$ Department of Medicine, Harvard Medical School, Boston, MA 02115, USA. ${ }^{6}$ Department of Medical Oncology, Dana-Farber Cancer Institute, Boston, MA 02115, USA.

Published: 31 July 2013

\section{References}

1. The Human Microbiome Project Consortium: Structure, function and diversity of the healthy human microbiome. Nature 2012, 486:207-214.

2. Eckburg PB, Bik EM, Bernstein CN, Purdom E, Dethlefsen L, Sargent M, Gill SR, Nelson KE, Relman DA: Diversity of the human intestinal microbial flora. Science 2005, 308:1635-1638.

3. Jostins L, Ripke S, Weersma RK, Duerr RH, McGovern DP, Hui KY, Lee JC, Schumm LP, Sharma Y, Anderson CA, Essers J, Mitrovic M, Ning K, Cleynen I, Theatre E, Spain SL, Raychaudhuri S, Goyette P, Wei Z, Abraham C, Achkar JP, Ahmad T, Amininejad L, Ananthakrishnan AN, Andersen V, Andrews JM, Baidoo L, Balschun T, Bampton PA, Bitton A, et al:: Host-microbe interactions have shaped the genetic architecture of inflammatory bowel disease. Nature 2012, 491:119-124.

4. Arthur JC, Perez-Chanona E, Mühlbauer M, Tomkovich S, Uronis JM, Fan TJ, Campbell BJ, Abujamel T, Dogan B, Rogers AB, Rhodes JM, Stintzi A, Simpson KW, Hansen JJ, Keku TO, Fodor AA, Jobin C: Intestinal inflammation targets cancer-inducing activity of the microbiota. Science 2012, 338:120-123.

5. Wen L, Ley RE, Volchkov PY, Stranges PB, Avanesyan L, Stonebraker AC, Hu C, Wong FS, Szot GL, Bluestone JA, Gordon JI, Chervonsky AV: Innate immunity and intestinal microbiota in the development of Type 1 diabetes. Nature 2008, 455:1109-1113.

6. Smith MI, Yatsunenko T, Manary MJ, Trehan I, Mkakosya R, Cheng J, Kau AL, Rich SS, Concannon P, Mychaleckyj JC, Liu J, Houpt E, Li JV, Holmes E, Nicholson J, Knights D, Ursell LK, Knight R, Gordon Jl: Gut microbiomes of Malawian twin pairs discordant for kwashiorkor. Science 2013, 339:548-554.

7. Claesson MJ, Jeffery IB, Conde S, Power SE, O'Connor EM, Cusack S, Harris HM, Coakley M, Lakshminarayanan B, O'Sullivan O, Fitzgerald GF, Deane J, O'Connor M, Harnedy N, O'Connor K, O'Mahony D, van Sinderen D, Wallace M, Brennan L, Stanton C, Marchesi JR, Fitzgerald AP, Shanahan F, Hill C, Ross RP, O'Toole PW: Gut microbiota composition correlates with diet and health in the elderly. Nature 2012, 488:178-184.

8. Arumugam M, Raes J, Pelletier E, Le Paslier D, Yamada T, Mende DR, Fernandes GR, Tap J, Bruls T, Batto JM, Bertalan M, Borruel N, Casellas F, Fernandez L, Gautier L, Hansen T, Hattori M, Hayashi T, Kleerebezem M, Kurokawa K, Leclerc M, Levenez F, Manichanh C, Nielsen HB, Nielsen T, Pons N, Poulain J, Qin J, Sicheritz-Ponten T, Tims $S$, et al:: Enterotypes of the human gut microbiome. Nature 2011, 473:174-180.

9. De Filippo C, Cavalieri D, Di Paola M, Ramazzotti M, Poullet JB, Massart S, Collini S, Pieraccini G, Lionetti P: Impact of diet in shaping gut microbiota revealed by a comparative study in children from Europe and rural Africa. Proc Natl Acad Sci U S A 2010, 107:14691-14696.

10. Dessein $R$, Peyrin-Biroulet $L$, Chamaillard M: Intestinal microbiota gives a nod to the hygiene hypothesis in type 1 diabetes. Gastroenterology 2009, 137:381-383.

11. Cho I, Yamanishi S, Cox L, Methé BA, Zavadil J, Li K, Gao Z, Mahana D, Raju K, Teitler I, Li H, Alekseyenko AV, Blaser MJ: Antibiotics in early life alter the murine colonic microbiome and adiposity. Nature 2012, 488:621-626.

12. Kinross JM, Darzi AW, Nicholson JK: Gut microbiome-host interactions in health and disease. Genome Med 2011, 3:14.

13. Xavier RJ, Podolsky DK: Unravelling the pathogenesis of inflammatory bowel disease. Nature 2007, 448:427-434.

14. Delzenne NM, Neyrinck AM, Backhed F, Cani PD: Targeting gut microbiota in obesity: effects of prebiotics and probiotics. Nat Rev Endocrino/ 2011, 7:639-646.

15. Foster JA, McVey Neufeld KA: Gut-brain axis: how the microbiome influences anxiety and depression. Trends Neurosci 2013, 36:305-312.

16. Wu HJ, Ivanov, II, Darce J, Hattori K, Shima T, Umesaki Y, Littman DR, Benoist C, Mathis D: Gut-residing segmented filamentous bacteria drive autoimmune arthritis via Thelper 17 cells. Immunity 2010, 32:815-827.

17. Penders J, Thijs C, van den Brandt PA, Kummeling I, Snijders B, Stelma F, Adams $H$, van Ree R, Stobberingh EE: Gut microbiota composition and development of atopic manifestations in infancy: the KOALA Birth Cohort Study. Gut 2007, 56:661-667.

18. Watanabe S, Narisawa Y, Arase S, Okamatsu H, Ikenaga T, Tajiri Y, Kumemura M: Differences in fecal microflora between patients with atopic dermatitis and healthy control subjects. J Allergy Clin Immunol 2003, 111:587-591.

19. Turnbaugh PJ, Gordon Jl: An invitation to the marriage of metagenomics and metabolomics. Cell 2008, 134:708-713.

20. Sharon I, Morowitz MJ, Thomas BC, Costello EK, Relman DA, Banfield JF: Time series community genomics analysis reveals rapid shifts in bacterial species, strains, and phage during infant gut colonization. Genome Res 2013, 23:111-120.

21. Qin J, Li R, Raes J, Arumugam M, Burgdorf KS, Manichanh C, Nielsen T, Pons N, Levenez F, Yamada T, Mende DR, Li J, Xu J, Li S, Li D, Cao J, Wang B, Liang H, Zheng H, Xie Y, Tap J, Lepage P, Bertalan M, Batto JM, Hansen T, Le Paslier D, Linneberg A, Nielsen HB, Pelletier E, Renault P, et al:: A human gut microbial gene catalogue established by metagenomic sequencing. Nature 2010, 464:59-65.

22. Saei AA, Barzegari A: The microbiome: the forgotten organ of the astronaut's body--probiotics beyond terrestrial limits. Future Microbiol 2012, 7:1037-1046.

23. Rahija RJ: Gnotobiotics. In The Mouse in Biomedical Research. 2nd edition. Edited by James GF, Muriel TD, Fred WQ, Stephen WB, Christian EN, Smith AL. Burlington: Academic Press; 2007:217-233.

24. Perse $M$, Cerar A: Dextran sodium sulphate colitis mouse model: traps and tricks. J Biomed Biotechnol 2012, 2012:718617.

25. Ananthakrishnan AN: Environmental triggers for inflammatory bowel disease. Curr Gastroenterol Rep 2013, 15:302.

26. Kim YG, Kamada N, Shaw MH, Warner N, Chen GY, Franchi L, Nunez G: The Nod2 sensor promotes intestinal pathogen eradication via the chemokine CCL2-dependent recruitment of inflammatory monocytes. Immunity 2011, 34:769-780.

27. Krishnan AV, Feldman D: Mechanisms of the anti-cancer and antiinflammatory actions of vitamin D. Annu Rev Pharmacol Toxicol 2011, 51:311-336.

28. White $\mathrm{JH}$ : Vitamin D signaling, infectious diseases, and regulation of innate immunity. Infect Immun 2008, 76:3837-3843.

29. Adorini L, Penna G: Dendritic cell tolerogenicity: a key mechanism in immunomodulation by vitamin D receptor agonists. Hum Immuno/ 2009, 70:345-352.

30. Wu S, Liao AP, Xia Y, Li YC, Li JD, Sartor RB, Sun J: Vitamin D receptor negatively regulates bacterial-stimulated NF-kB activity in intestine. Am J Pathol 2010, 177:686-697.

31. Willing BP, Dicksved J, Halfvarson J, Andersson AF, Lucio M, Zheng Z, Jarnerot G, Tysk C, Jansson JK, Engstrand L: A pyrosequencing study in twins shows that gastrointestinal microbial profiles vary with inflammatory bowel disease phenotypes. Gastroenterology 2010, 139:1844-1854.

32. Morgan XC, Tickle TL, Sokol H, Gevers D, Devaney KL, Ward DV, Reyes JA, Shah SA, LeLeiko N, Snapper SB, Bousvaros A, Korzenik J, Sands BE, Xavier RJ, Huttenhower C: Dysfunction of the intestinal microbiome in inflammatory 
bowel disease and treatment. Genome Biol 2012, 13:R79.

33. Winter SE, Lopez CA, Baumler AJ: The dynamics of gut-associated microbial communities during inflammation. EMBO Rep 2013, 14:319-327.

34. Lemon KP, Armitage GC, Relman DA, Fischbach MA: Microbiota-targeted therapies: an ecological perspective. Sci Trans/ Med 2012, 4:137rv135.

35. Smith PM, Howitt MR, Panikov N, Michaud M, Gallini C, Bohlooly-Y M, Glickman JN, Garrett WS: The microbial metabolites, short chain fatty acids, regulate colonic $\mathrm{T}_{\text {reg }}$ cell homeostasis. Science 2013. doi: 10.1126/science. 1241165

36. de Pablo P, Dietrich T, McAlindon TE: Association of periodontal disease and tooth loss with rheumatoid arthritis in the US population. J Rheumatol 2008, 35:70-76.

37. Hayashi H, Satoi K, Sato-Mito N, Kaburagi T, Yoshino H, Higaki M, Nishimoto K, Sato K: Nutritional status in relation to adipokines and oxidative stress is associated with disease activity in patients with rheumatoid arthritis. Nutrition 2012, 28:1109-1114.

38. Vaahtovuo J, Munukka E, Korkeamaki M, Luukkainen R, Toivanen P: Fecal microbiota in early rheumatoid arthritis. J Rheumato/ 2008, 35:1500-1505.

39. Abdollahi-Roodsaz S, Joosten LA, Koenders MI, Devesa I, Roelofs MF, Radstake TR, Heuvelmans-Jacobs M, Akira S, Nicklin MJ, Ribeiro-Dias F, van den Berg WB: Stimulation of TLR2 and TLR4 differentially skews the balance of T cells in a mouse model of arthritis. J Clin Invest 2008, 118:205-216.

40. Horai R, Saijo S, Tanioka H, Nakae S, Sudo K, Okahara A, Ikuse T, Asano M, Iwakura Y: Development of chronic inflammatory arthropathy resembling rheumatoid arthritis in interleukin 1 receptor antagonist-deficient mice. J Exp Med 2000, 191:313-320

41. Yazdanbakhsh M, Kremsner PG, van Ree R: Allergy, parasites, and the hygiene hypothesis. Science 2002, 296:490-494.

42. Hamelmann E, Beyer K, Gruber C, Lau S, Matricardi PM, Nickel R, Niggemann B, Wahn U: Primary prevention of allergy: avoiding risk or providing protection? Clin Exp Allergy 2008, 38:233-245.

43. Finn PW, Boudreau JO, He H, Wang Y, Chapman MD, Vincent C, Burge HA, Weiss ST, Perkins DL, Gold DR: Children at risk for asthma: home allergen levels, lymphocyte proliferation, and wheeze. J Allergy Clin Immunol 2000, 105:933-942.

44. Kong HH, Oh J, Deming C, Conlan S, Grice EA, Beatson MA, Nomicos E, Polley EC, Komarow HD, NISC Comparative Sequence Program, Murray PR, Turner ML, Segre JA: Temporal shifts in the skin microbiome associated with disease flares and treatment in children with atopic dermatitis. Genome Res 2012, 22:850-859.

45. Mikami K, Takahashi H, Kimura M, Isozaki M, Izuchi K, Shibata R, Sudo N,

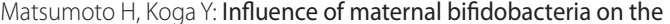
establishment of bifidobacteria colonizing the gut in infants. Pediatr Res 2009, 65:669-674

46. Lange NE, Celedón JC, Forno E, Ly NP, Onderdonk A, Bry L, Delaney ML, DuBois AM, Gold DR, Weiss ST, Litonjua AA: Maternal intestinal flora and wheeze in early childhood. Clin Exp Allergy 2012, 42:901-908.

47. Forsythe P, Kunze WA: Voices from within: gut microbes and the CNS. Cell Mol Life Sci 2013, 70:55-69.

48. Diaz Heijtz R, Wang S, Anuar F, Qian Y, Bjorkholm B, Samuelsson A, Hibberd ML, Forssberg H, Pettersson S: Normal gut microbiota modulates brain development and behavior. Proc Natl Acad Sci U S A 2011, 108:3047-3052.

49. Sudo N, Chida Y, Aiba Y, Sonoda J, Oyama N, Yu XN, Kubo C, Koga Y: Postnatal microbial colonization programs the hypothalamic-pituitary-adrena system for stress response in mice. J Physio/ 2004, 558:263-275.

50. Sharon G, Segal D, Ringo JM, Hefetz A, Zilber-Rosenberg I, Rosenberg E: Commensal bacteria play a role in mating preference of Drosophila melanogaster. Proc Natl Acad Sci U S A 2010, 107:20051-20056.

51. Bravo JA, Forsythe P, Chew MV, Escaravage E, Savignac HM, Dinan TG, Bienenstock J, Cryan JF: Ingestion of Lactobacillus strain regulates emotional behavior and central GABA receptor expression in a mouse via the vagus nerve. Proc Natl Acad Sci U S A 2011, 108:16050-16055.

52. O'Mahony SM, Marchesi JR, Scully P, Codling C, Ceolho AM, Quigley EM, Cryan JF, Dinan TG: Early life stress alters behavior, immunity, and microbiota in rats: implications for irritable bowel syndrome and psychiatric illnesses. Biol Psychiatry 2009, 65:263-267.

53. Liou AP, Paziuk M, Luevano JM, Jr., Machineni S, Turnbaugh PJ, Kaplan LM: Conserved shifts in the gut microbiota due to gastric bypass reduce host weight and adiposity. Sci Trans/ Med 2013, 5:178ra141

54. Weiner HL: The challenge of multiple sclerosis: how do we cure a chronic heterogeneous disease? Ann Neuro/ 2009, 65:239-248.
55. Tselis A: Epstein-Barr virus cause of multiple sclerosis. Curr Opin Rheumatol 2012, 24:424-428.

56. Lee J, Sandor M, Heninger E, Fabry Z: Mycobacteria-induced suppression of autoimmunity in the central nervous system. J Neuroimmune Pharmacol 2010, 5:210-219.

57. Paolillo A, Buzzi MG, Giugni E, Sabatini U, Bastianello S, Pozzilli C, Salvetti M, Ristori G: The effect of Bacille Calmette-Guerin on the evolution of new enhancing lesions to hypointense T1 lesions in relapsing remitting MS. J Neurol 2003, 250:247-248.

58. Ellestad KK, Tsutsui S, Noorbakhsh F, Warren KG, Yong VW, Pittman QJ, Power C: Early life exposure to lipopolysaccharide suppresses experimental autoimmune encephalomyelitis by promoting tolerogenic dendritic cells and regulatory T cells. J Immuno/ 2009, 183:298-309.

59. Segata N, Boernigen D, Tickle TL, Morgan XC, Garrett WS, Huttenhower C Computational meta'omics for microbial community studies. Mol Syst Biol 2013. doi: 10.1038/msb.2013.22.

60. Tringe $S G$, Hugenholtz $P$ : A renaissance for the pioneering $16 S$ rRNA gene. Curr Opin Microbiol 2008, 11:442-446.

61. Tyson GW, Chapman J, Hugenholtz P, Allen EE, Ram RJ, Richardson PM Solovyev V, Rubin EM, Rokhsar DS, Banfield JF: Community structure and metabolism through reconstruction of microbial genomes from the environment. Nature 2004, 428:37-43.

62. Verberkmoes NC, Russell AL, Shah M, Godzik A, Rosenquist M, Halfvarson J, Lefsrud MG, Apajalahti J, Tysk C, Hettich RL, Jansson JK: Shotgun metaproteomics of the human distal gut microbiota. ISME J 2009, 3:179-189.

63. Wikoff WR, Anfora AT, Liu J, Schultz PG, Lesley SA, Peters EC, Siuzdak G: Metabolomics analysis reveals large effects of gut microflora on mammalian blood metabolites. Proc Natl Acad Sci U S A 2009. 106:3698-3703.

64. Kuczynski J, Lauber CL, Walters WA, Parfrey LW, Clemente JC, Gevers D, Knigh $\mathrm{R}$ : Experimental and analytical tools for studying the human microbiome. Nat Rev Genet 2012, 13:47-58.

65. Jumpstart Consortium Human Microbiome Project Data Generation Working Group: Evaluation of 16S rDNA-based community profiling for human microbiome research. PLoS One 2012, 7:e39315.

66. Tatusov RL, Koonin EV, Lipman DJ: A genomic perspective on protein families. Science 1997, 278:631-637.

67. Powell S, Szklarczyk D, Trachana K, Roth A, Kuhn M, Muller J, Arnold R, Rattei T, Letunic I, Doerks T, Jensen LJ, von Mering C, Bork P: eggNOG v3.0: orthologous groups covering 1133 organisms at 41 different taxonomic ranges. Nucleic Acids Res 2012, 40:D284-289.

68. Punta M, Coggill PC, Eberhardt RY, Mistry J, Tate J, Boursnell C, Pang N, Forslund K, Ceric G, Clements J, Heger A, Holm L, Sonnhammer EL, Eddy SR, Bateman A, Finn RD: The Pfam protein families database. Nucleic Acids Res 2012, 40:D290-301.

69. Suzek BE, Huang H, McGarvey P, Mazumder R, Wu CH: UniRef: comprehensive and non-redundant UniProt reference clusters. Bioinformatics 2007, 23:1282-1288.

70. Langille MG, Zaneveld J, Caporaso JG, McDonald D, Knights D, Reyes JA, Clemente JC, Knight R, Beiko RG, Huttenhower C: Predictive functional profiling of microbial communities using 16S rRNA marker gene sequences. Nat Biotechnol, in press.

71. Kanehisa M, Goto S: KEGG: Kyoto encyclopedia of genes and genomes. Nucleic Acids Res 2000, 28:27-30.

72. Caspi R, Altman T, Dreher K, Fulcher CA, Subhraveti P, Keseler IM, Kothari A, Krummenacker M, Latendresse M, Mueller LA, Ong Q, Paley S, Pujar A, Shearer AG, Travers M, Weerasinghe D, Zhang P, Karp PD: The MetaCyc database of metabolic pathways and enzymes and the BioCyc collection of pathway/ genome databases. Nucleic Acids Res 2012, 40:D742-753.

73. Overbeek R, Begley T, Butler RM, Choudhuri JV, Chuang HY, Cohoon M, de Crécy-Lagard V, Diaz N, Disz T, Edwards R, Fonstein M, Frank ED, Gerdes S, Glass EM, Goesmann A, Hanson A, Iwata-Reuyl D, Jensen R, Jamshidi N, Krause L, Kubal M, Larsen N, Linke B, McHardy AC, Meyer F, Neuweger H, Olsen G, Olson R, Osterman A, Portnoy V, et al.: The subsystems approach to genome annotation and its use in the project to annotate 1000 genomes. Nucleic Acids Res 2005, 33:5691-5702.

74. Markowitz VM, Chen IM, Chu K, Szeto E, Palaniappan K, Grechkin Y, Ratner A, Jacob B, Pati A, Huntemann M, Liolios K, Pagani I, Anderson I, Mavromatis K, Ivanova NN, Kyrpides NC: IMG/M: the integrated metagenome data management and comparative analysis system. Nucleic Acids Res 2012, 
40:D123-129

75. Meyer F, Paarmann D, D'Souza M, Olson R, Glass EM, Kubal M, Paczian T, Rodriguez A, Stevens R, Wilke A, Wilkening J, Edwards RA: The metagenomics RAST server - a public resource for the automatic phylogenetic and functional analysis of metagenomes. BMC Bioinformatics 2008, 9:386.

76. Huson DH, Auch AF, Qi J, Schuster SC: MEGAN analysis of metagenomic data. Genome Res 2007, 17:377-386

77. Abubucker S, Segata N, Goll J, Schubert AM, Izard J, Cantarel BL, RodriguezMueller B, Zucker J, Thiagarajan M, Henrissat B, White O, Kelley ST, Methé B, Schloss PD, Gevers D, Mitreva M, Huttenhower C: Metabolic reconstruction for metagenomic data and its application to the human microbiome. PLoS Comput Biol 2012, 8:e1002358.

78. Liu B, Pop M: ARDB--Antibiotic Resistance Genes Database. Nucleic Acids Res 2009, 37:D443-447.

79. Maurice CF, Haiser HJ, Turnbaugh PJ: Xenobiotics shape the physiology and gene expression of the active human gut microbiome. Cell 2013, 152:39-50.

80. Haiser HJ, Turnbaugh PJ: Developing a metagenomic view of xenobiotic metabolism. Pharmacol Res 2013, 69:21-31.

81. The Human Microbiome Project Consortium: A framework for human microbiome research. Nature 2012, 486:215-221.

82. National Institutes of Health Human Microbiome Project [http://hmpdacc.org]

83. Aagaard K, Petrosino J, Keitel W, Watson M, Katancik J, Garcia N, Patel S, Cutting M, Madden T, Hamilton H, Harris E, Gevers D, Simone G, McInnes P, Versalovic J: The Human Microbiome Project strategy for comprehensive sampling of the human microbiome and why it matters. FASEB J 2013 27:1012-1022.

84. Segata N, Haake SK, Mannon P, Lemon KP, Waldron L, Gevers D, Huttenhower C, lzard J: Composition of the adult digestive tract bacterial microbiome based on seven mouth surfaces, tonsils, throat and stool samples. Genome Biol 2012, 13:R42.

85. Chervonsky AV: Influence of microbial environment on autoimmunity. Nat Immunol 2010, 11:28-35.

86. Presley LL, Ye J, Li X, Leblanc J, Zhang Z, Ruegger PM, Allard J, McGovern D, Ippoliti A, Roth B, Cui X, Jeske DR, Elashoff D, Goodglick L, Braun J, Borneman $\mathrm{J}$ : Host-microbe relationships in inflammatory bowel disease detected by bacterial and metaproteomic analysis of the mucosal-luminal interface. Inflamm Bowel Dis 2012, 18:409-417.

87. Ballal SA, Gallini CA, Segata N, Huttenhower C, Garrett WS: Host and gut microbiota symbiotic factors: lessons from inflammatory bowel disease and successful symbionts. Cell Microbiol 2011, 13:508-517.

88. Lau S: What is new in the prevention of atopy and asthma? Curr Opin Allergy Clin Immunol 2013, 13:181-186.

89. Turnbaugh PJ, Hamady M, Yatsunenko T, Cantarel BL, Duncan A, Ley RE, Sogin ML, Jones WJ, Roe BA, Affourtit JP, Egholm M, Henrissat B, Heath AC, Knight R, Gordon Jl: A core gut microbiome in obese and lean twins. Nature 2009, 457:480-484.

90. Hildebrandt MA, Hoffmann C, Sherrill-Mix SA, Keilbaugh SA, Hamady M, Chen YY, Knight R, Ahima RS, Bushman F, Wu GD: High-fat diet determines the composition of the murine gut microbiome independently of obesity. Gastroenterology 2009, 137:1716-1724.

91. Brown CT, Davis-Richardson AG, Giongo A, Gano KA, Crabb DB, Mukherjee N, Casella G, Drew JC, Ilonen J, Knip M, Hyöty H, Veijola R, Simell T, Simell O, Neu J, Wasserfall CH, Schatz D, Atkinson MA, Triplett EW: Gut microbiome metagenomics analysis suggests a functional model for the development of autoimmunity for type 1 diabetes. PloS One 2011, 6:e25792.

92. Bach JF: The effect of infections on susceptibility to autoimmune and allergic diseases. N Engl J Med 2002, 347:911-920.

93. Markle JG, Frank DN, Mortin-Toth S, Robertson CE, Feazel LM, Rolle-Kampczyk $U$, von Bergen M, McCoy KD, Macpherson AJ, Danska JS: Sex differences in the gut microbiome drive hormone-dependent regulation of autoimmunity. Science 2013, 339:1084-1088.

94. Qin J, Li Y, Cai Z, Li S, Zhu J, Zhang F, Liang S, Zhang W, Guan Y, Shen D, Peng Y, Zhang D, Jie Z, Wu W, Qin Y, Xue W, Li J, Han L, Lu D, Wu P, Dai Y, Sun X, Li Z, Tang A, Zhong S, Li X, Chen W, Xu R, Wang M, Feng Q, et al:: A metagenomewide association study of gut microbiota in type 2 diabetes. Nature 2012, 490:55-60.

95. Naik S, Bouladoux N, Wilhelm C, Molloy MJ, Salcedo R, Kastenmuller W, Deming C, Quinones M, Koo L, Conlan S, Spencer S, Hall JA, Dzutsev A, Kong H, Campbell DJ, Trinchieri G, Segre JA, Belkaid Y: Compartmentalized control of skin immunity by resident commensals. Science 2012, 337:1115-1119.

96. Devkota S, Wang Y, Musch MW, Leone V, Fehlner-Peach H, Nadimpalli A, Antonopoulos DA, Jabri B, Chang EB: Dietary-fat-induced taurocholic acid promotes pathobiont expansion and colitis in $1 / 10^{-/}$mice. Nature 2012, 487:104-108.

97. Kostic AD, Howitt MR, Garrett WS: Exploring host-microbiota interactions in animal models and humans. Genes Dev 2013, 27:701-718.

98. Walter J, Ley R: The human gut microbiome: ecology and recent evolutionary changes. Annu Rev Microbio/ 2011, 65:411-429.

99. Hansen EE, Lozupone CA, Rey FE, Wu M, Guruge JL, Narra A, Goodfellow J, Zaneveld JR, McDonald DT, Goodrich JA, Heath AC, Knight R, Gordon Jl: Pan-genome of the dominant human gut-associated archaeon, Methanobrevibacter smithii, studied in twins. Proc Natl Acad Sci U S A 2011, 108 Suppl 1:4599-4606.

100. Stahringer SS, Clemente JC, Corley RP, Hewitt J, Knights D, Walters WA, Knight $R$, Krauter KS: Nurture trumps nature in a longitudinal survey of salivary bacterial communities in twins from early adolescence to early adulthood. Genome Res 2012, 22:2146-2152.

101. Dethlefsen L, Relman DA: Incomplete recovery and individualized responses of the human distal gut microbiota to repeated antibiotic perturbation. Proc Natl Acad Sci U S A 2011, 108 Suppl 1:4554-4561.

102. McNulty NP, Yatsunenko T, Hsiao A, Faith JJ, Muegge BD, Goodman AL, Henrissat B, Oozeer R, Cools-Portier S, Gobert G, Chervaux C, Knights D, Lozupone CA, Knight R, Duncan AE, Bain JR, Muehlbauer MJ, Newgard CB, Heath AC, Gordon Jl: The impact of a consortium of fermented milk strains on the gut microbiome of gnotobiotic mice and monozygotic twins. SciTrans/Med 2011, 3:106ra106.

103. Toprak E, Veres A, Michel JB, Chait R, Hartl DL, Kishony R: Evolutionary paths to antibiotic resistance under dynamically sustained drug selection. Nat Genet 2012, 44:101-105.

104. Gonzalez A, King A, Robeson MS, 2nd, Song S, Shade A, Metcalf JL, Knight R: Characterizing microbial communities through space and time. Curr Opin Biotechnol 2012, 23:431-436.

105. Wu GD, Chen J, Hoffmann C, Bittinger K, Chen YY, Keilbaugh SA, Bewtra M, Knights D, Walters WA, Knight R, Sinha R, Gilroy E, Gupta K, Baldassano R, Nessel L, Li H, Bushman FD, Lewis JD: Linking long-term dietary patterns with gut microbial enterotypes. Science 2011, 334:105-108.

106. Turnbaugh PJ, Ridaura VK, Faith JJ, Rey FE, Knight R, Gordon JI: The effect of diet on the human gut microbiome: a metagenomic analysis in humanized gnotobiotic mice. Sci Trans/ Med 2009, 1:6ra14.

107. Joossens M, Huys G, Cnockaert M, De Preter V, Verbeke K, Rutgeerts P, Vandamme P, Vermeire S: Dysbiosis of the faecal microbiota in patients with Crohn's disease and their unaffected relatives. Gut 2011, 60:631-637.

108. Peterfreund GL, Vandivier LE, Sinha R, Marozsan AJ, Olson WC, Zhu J, Bushman FD: Succession in the gut microbiome following antibiotic and antibody therapies for Clostridium difficile. Plos One 2012, 7:e46966.

109. Sartor RB: Mechanisms of disease: pathogenesis of Crohn's disease and ulcerative colitis. Nat Clin Pract Gastroenterol Hepatol 2006, 3:390-407.

110. Barratt BJ, Payne F, Lowe CE, Hermann R, Healy BC, Harold D, Concannon P, Gharani N, McCarthy MI, Olavesen MG, McCormack R, Guja C, lonescuTîrgovişte C, Undlien DE, Rønningen KS, Gillespie KM, Tuomilehto-Wolf E, Tuomilehto J, Bennett ST, Clayton DG, Cordell HJ, Todd JA: Remapping the insulin gene/IDDM2 locus in type 1 diabetes. Diabetes 2004, 53:1884-1889.

111. Bottini N, Musumeci L, Alonso A, Rahmouni S, Nika K, Rostamkhani M, MacMurray J, Meloni GF, Lucarelli P, Pellecchia M, Eisenbarth GS, Comings D, Mustelin T: A functional variant of lymphoid tyrosine phosphatase is associated with type I diabetes. Nat Genet 2004, 36:337-338.

112. Polychronakos C, Li Q: Understanding type 1 diabetes through genetics: advances and prospects. Nat Rev Genet 2011, 12:781-792.

113. Ueda H, Howson JM, Esposito L, Heward J, Snook H, Chamberlain G, Rainbow DB, Hunter KM, Smith AN, Di Genova G, Herr MH, Dahlman I, Payne F, Smyth D, Lowe C, Twells RC, Howlett S, Healy B, Nutland S, Rance HE, Everett V, Smink LJ, Lam AC, Cordell HJ, Walker NM, Bordin C, Hulme J, Motzo C, Cucca F, Hess JF, et al: Association of the T-cell regulatory gene CTLA4 with susceptibility to autoimmune disease. Nature 2003, 423:506-511.

114. Qu HQ, Montpetit A, Ge B, Hudson TJ, Polychronakos C: Toward further mapping of the association between the IL2RA locus and type 1 diabetes. Diabetes 2007, 56:1174-1176.

115. Smyth DJ, Cooper JD, Bailey R, Field S, Burren O, Smink LJ, Guja C, IonescuTirgoviste C, Widmer B, Dunger DB, Savage DA, Walker NM, Clayton DG, Todd JA: A genome-wide association study of nonsynonymous SNPs identifies a 
type 1 diabetes locus in the interferon-induced helicase (IFIH1) region. Nat Genet 2006, 38:617-619.

116. Li M, Zhou Y, Feng G, Su SB: The critical role of Toll-like receptor signaling pathways in the induction and progression of autoimmune diseases. Curr Mol Med 2009, 9:365-374

117. Scher JU, Abramson SB: The microbiome and rheumatoid arthritis. Nat Rev Rheumatol 2011, 7:569-578

118. Yeoh N, Burton JP, Suppiah P, Reid G, Stebbings S: The role of the microbiome in rheumatic diseases. Curr Rheumatol Rep 2013, 15:314

119. Cavanillas ML, Alcina A, Núñez C, de las Heras V, Fernández-Arquero M, Bartolomé M, de la Concha EG, Fernández O, Arroyo R, Matesanz F, Urcelay E: Polymorphisms in the IL2, IL2RA and IL2RB genes in multiple sclerosis risk. Eur J Hum Genet 2010, 18:794-799.

120. Lundmark F, Duvefelt K, lacobaeus E, Kockum I, Wallström E, Khademi M, Oturai A, Ryder LP, Saarela J, Harbo HF, Celius EG, Salter H, Olsson T, Hillert J: Variation in interleukin 7 receptor alpha chain (IL7R) influences risk of multiple sclerosis. Nat Genet 2007, 39:1 108-1113.

121. Gourraud PA, Harbo HF, Hauser SL, Baranzini SE: The genetics of multiple sclerosis: an up-to-date review. Immunol Rev 2012, 248:87-103.

122. Ly NP, Ruiz-Pérez B, Onderdonk AB, Tzianabos AO, Litonjua AA, Liang C, Laskey D, Delaney ML, DuBois AM, Levy H, Gold DR, Ryan LM, Weiss ST, Celedón JC: Mode of delivery and cord blood cytokines: a birth cohort study. Clin Mol Allergy 2006, 4:13.
123. Cookson W: The alliance of genes and environment in asthma and allergy Nature 1999, 402:B5-11.

124. Searing DA, Leung DY: Vitamin D in atopic dermatitis, asthma and allergic diseases. Immunol Allergy Clin North Am 2010, 30:397-409.

125. O'Regan GM, Sandilands A, McLean WH, Irvine AD: Filaggrin in atopic dermatitis. J Allergy Clin Immunol 2008, 122:689-693.

126. Martinez FD: CD14, endotoxin, and asthma risk: actions and interactions. Proc Am Thorac Soc 2007, 4:221-225.

127. Ober C, Hoffjan S: Asthma genetics 2006: the long and winding road to gene discovery. Genes Immun 2006, 7:95-100

128. Noval Rivas M, Burton OT, Wise P, Zhang YQ, Hobson SA, Garcia Lloret M, Chehoud C, Kuczynski J, DeSantis T, Warrington J, Hyde ER, Petrosino JF, Gerber GK, Bry L, Oettgen HC, Mazmanian SK, Chatila TA: A microbiota signature associated with experimental food allergy promotes allergic sensitization and anaphylaxis. J Allergy Clin Immunol 2013, 131:201-212.

doi:10.1186/gm469

Cite this article as: Börnigen $D$, et al.: Functional profiling of the gut microbiome in disease-associated inflammation. Genome Medicine 2013 5:65. 